\title{
Analysis of complicating risk factors of Type 2 Diabetes Mellitus (T2DM)
}

\author{
Resal Raj ${ }^{1}$, Silvia Navis ${ }^{5}$, Jasvinder Singh Bhatti ${ }^{2}$, Sanjay Kumar Bhadada ${ }^{3}$ and Pramod W Ramteke \\ ${ }^{1}$ Department of Computational Biology\& Bioinformatics, Sam Higginbottom University of Agriculture, Technology and Sciences, Allahabad, UP, India \\ ${ }^{2}$ Department of Biotechnology \&Bioinformatics, SGGC College, Sector 26, Chandigarh, India \\ ${ }^{3}$ Department of Endocrinology, PGIMER, Chandigarh, India \\ ${ }^{4}$ Department of Biological Sciences, Sam Higginbottom University of Agriculture, Technology and Sciences, Allahabad, UP, India \\ ${ }^{5}$ School of Health Sciences, The University of Dodoma, Dodoma, Tanzania
}

\begin{abstract}
Background: Type 2 diabetes mellitus (T2DM) is a complicated disease affecting different populations and the starting age of subjects is as early as 15 years old. Since anthropometric, clinical and genetic risk factors are associated with the development of T2DM, the complications developed due to T2DM are life-threatening. Therefore, this research analyzes the complicating risk factors of T2DM.
\end{abstract}

Materials and methods: An observational study of approximately 10,000 north Indian individuals were contacted and a total of 703 subjects (351 control subjects and 352 T2DM subjects) belonging to north Indian states were recruited for the analysis of the risk factors.

Result: Very early onset of T2DM, very large undiagnosed population, high newly diagnosed T2DM subjects, independent effect of complicating risk factors etc. were the results obtained from the research.

Conclusion: Considering the complications and early onset of T2DM, despite the other diseases along with T2DM, early mortality and increased mortality due to T2DM were observed in north Indian population.

\section{Introduction}

Diabetes is common among almost all people [1], ages and regions of the globe due to changes in lifestyle, genetics and environmental factors which all collectively influence the disorder. T2DM appears to be due to number of different defects in insulin secretion [2], insulin's inhibitory effect on liver glucose production [3] etc. In case of pancreatic beta cell and insulin secretion, it has been suggested that increased free fatty acids, FFA in serum could precipitate $\beta$-cell failure [4]. Short-term exposure of pancreatic islets to FFA increases insulin secretion but long-term exposure inhibits glucose-induced insulin secretion and biosynthesis and may lead to $\beta$-cell death by apoptosis [5]. Increased insulin sensitivity promotes fat deposition in adipose tissue [6]. Elevated levels of non-esterified fatty acids (NEFAs) contribute to $\beta$-cell dysfunction, $\beta$-cell loss and lipotoxicity. Formation of $\mathrm{H} 2 \mathrm{O} 2$ in peroxisomes is responsible for NEFA-induced toxicity [7].

However, the main driver of the precipitation of T2DM is linked with changes in diet and very low physical activity, evidence from urban population [8]. Food affects the expression of genes in individuals, both diet and genes alter health of an individual because genes are regulated by diet and some diets are risk factors of T2DM [9]. Therefore, susceptibility depends on nutrient intake and environmental factors. Which may be, sleep duration and continuity [10], oxygen homeostasis [11], intake of anti-inflammatory drugs [12], intake of beverages like tea [13] physical inactivity [14] any form of stress [15] exposure to pollutants [16] etc.

Out of the risk factors, alcohol consumption, smoking and physical inactivity-induced insulin resistance in skeletal muscle [17] play a major role in the susceptibility to T2DM. There are much differences seen in insulin secretion and sensitivity and nonalcoholic fatty liver disease and T2DM in subjects with different risk factors [18]. However, new alcohol drinkers in middle age and drink rarely may experience benefit in cardiovascular disease and diabetic complication [19] whereas rare and light drinkers after increasing alcohol consumption over short period of time are associated with lower risk of T2DM [20]. Moreover, cigarette smoking and smoking cessation lead to higher short-term risk of T2DM [21].

The long term complications of T2DM are chronic complications in circulatory system that may cause blindness, lower limb gangrene and renal failure in adults. It is also a major risk factor for strokes and other cardiovascular diseases (CVD) [22]. Since T2DM is common, its related disorders such as nephropathy [23], neuropathy and retinopathy are also more common. Diabetic nephropathy is a serious complication of T2DM and the prevalence of nephropathy has been increasing worldwide [24, 25]. In subjects with CAD and T2DM, the complications lead to functional and structural vascular alterations of the peripheral

Correspondence to: Resal Raj, Department of Computational Biology\& Bioinformatics, Sam Higginbottom University of Agriculture, Technology and Sciences, Allahabad, UP, India, Tel: +919783599073; E-mail: resalraj@yahoo.com

Key words: Mortality, undiagnosed population, casual approach, newly diagnosed Received: March 02, 2018; Accepted: March 19, 2018; Published: March 26 2018 
vasculature [26]. Diabetic peripheral neuropathy can lead to infected ulcers and amputation of lower limbs. Huge database is available about the prevalence of diabetes neuropathy in T2DM [27] and T1DM [28]. World health organization (WHO) reports that diabetes will be the 7 th leading cause of death in 2030 [29]. T2DM increases mortality approximately two-fold of the subjects and micro and macro-vascular complications are the main cause of death [30]. Apart from this, in India the overall mortality rate is higher in diabetes compared to non-diabetic subjects and the mortality rate further split into different complications (cardiovascular - 52.9\%, renal causes - 23.5\%, gastrointestinal - $112.1 \%$, respiratory $-9.1 \%$, and lifestyle related $-6.1 \%)[31]$.

\section{Materials and Methodology}

In this research, a preliminary observation of incidence of T2DM subjects of approximately 10,000 was interviewed. Apart from this, 351 control and 352 T2DM subjects from nearby locations of Chandigarh belonging to the states of Haryana, Utter Pradesh, Himachal Pradesh, Jammu Kashmir, Punjab, Delhi, Rajasthan, West Bengal etc. and resident of Chandigarh, Panchkula, Mohali, Baltana, etc. were recruited. This is because these cities/towns have resident migrated populations of these states. They were recruited at referral points /schools / hospitals etc. to administer the questionnaire for the data capture for this research. The subjects were completely analyzed using the criteria for control and T2DM subjects specified by diabetes associations. A formal brochure explaining about the research was given to each participant and a signed consent form for the involvement of research was taken. An ethical committee approval was also obtained formally from the institutional ethical committee on human studies from Post graduate institute for medical education and research (PGIMER), sector 12 Chandigarh.

\section{Result}

Prevalence of T2DM and the reaction or approach to T2DM by the nonresident Chandigarh people of northern India (reaching hospitals from rural areas of the states) were assessed by one to one personal interaction during the three years of research and the details are given below, Table 1.

$18 \%$ of the surveyed people are on the hundred percent safe sides, taking care of diabetes medication and the rest are unsafe which may lead to the high prevalence of T2DM. To project the observation, a graph is drawn, Figure 1.

\section{Demographic and Socioeconomic characteristics}

The demographic and the T2DM associated socioeconomic (religion, cooking media, sex and age) characteristics of all subjects are summarized in the following, Table 2 .

\section{Details of year of onset, duration of onset of T2DM and Medication}

The year of onset, duration of onset and medication are tabled which shows that T2DM develops very early year of life span. The duration of onset below 5 years is very high, $64 \%$ and more than 20 years is very low only $2 \%$ of the population recruited. The medication is also surprising that total of $57 \%$ of the recruited population take medication and rest are not, Table 3 .

\section{Smoking, Drinking, Hypertension, CHD, Heredity and Physical Activity}

These risk factors are independent and are involved in the susceptibility to T2DM separately or collectively. The result shows $49 \%$

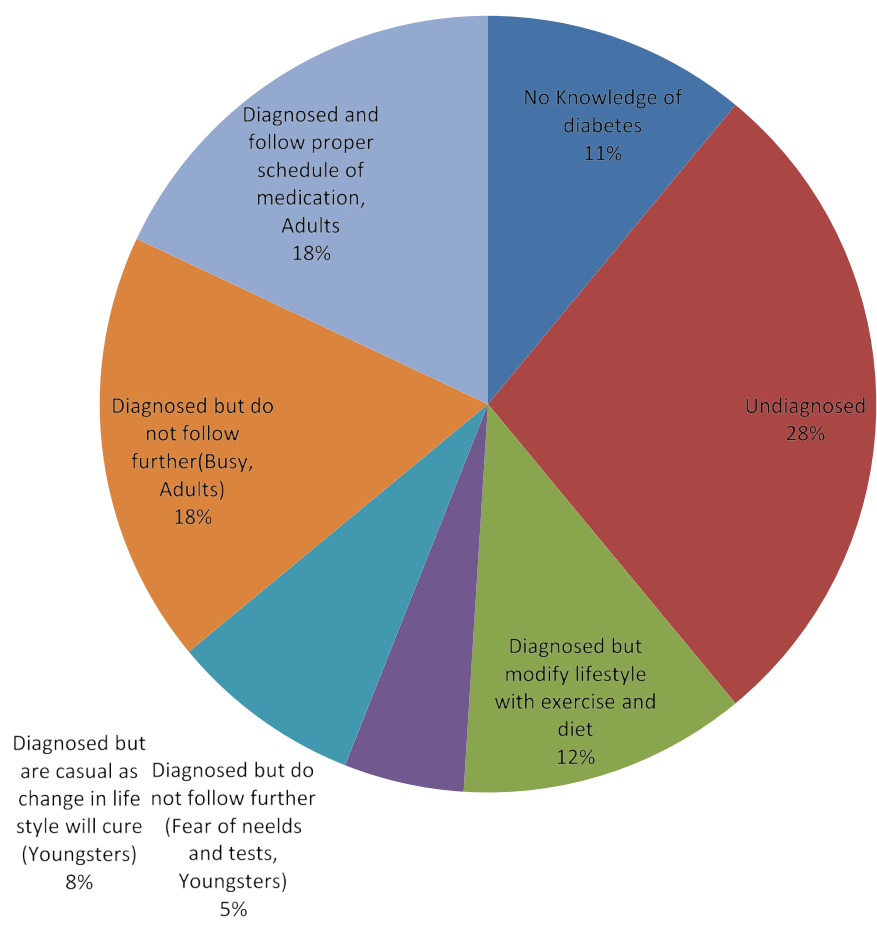

Figure 1. Knowledge perception of T2DM in north India.

Table 1. Knowledge Perception of T2DM among North Indian Population of 10,000 Subjects.

\begin{tabular}{|c|c|c|}
\hline Category & $\begin{array}{l}\text { Number of } \\
\text { Subjects* } \\
\text { (\%) }\end{array}$ & $\begin{array}{l}\text { Analysis } \\
(\%)\end{array}$ \\
\hline No Knowledge of diabetes & $1100(11)$ & \multirow{6}{*}{$8200(82)$} \\
\hline Undiagnosed & $2800(28)$ & \\
\hline Diagnosed but modify lifestyle with exercise and diet & $1200(12)$ & \\
\hline $\begin{array}{l}\text { Diagnosed but do not follow further (Fear of needles and } \\
\text { tests, Youngsters) }\end{array}$ & $500(5)$ & \\
\hline $\begin{array}{l}\text { Diagnosed but are casual as change in life style will cure } \\
\text { (Youngsters) }\end{array}$ & $800(8)$ & \\
\hline Diagnosed but do not follow further (Busy, Adults) & $1800(18)$ & \\
\hline Diagnosed and follow proper schedule of medication, Adults & $1800(18)$ & $1800(18)$ \\
\hline Total & $10,000(100)$ & \\
\hline
\end{tabular}

*Data shown is nearest to 100

of T2DM subjects have hypertension and it is an interlinked factor to the susceptibility of T2DM, Table 4.

\section{Details of complications}

While collecting the data, all the complications were analyzed such as retinopathy and cataract due to T2DM, neuropathy, amputation and diabetes foot and all were given importance due to chronic effect of these factors to T2DM. Moreover, to know other diseases complicate T2DM or T2DM complicates other diseases, a historical analysis of subjects having skin disease, stroke, cancer, asthma, thyroid and Arthritis were analyzed with those who were having onset of T2DM more than 5 years, Table 5 .

\section{Discussion}

Chandigarh contains populations from different states of North India and $57 \%$ of the control and $61 \%$ of T2DM participants are resident 
Table 2. Religion, Cooking Media, Sex and Age of north Indian population.

\begin{tabular}{|c|c|c|c|}
\hline & Control (\%) & T2DM (\%) & \\
\hline \multicolumn{3}{|l|}{ Religion } & Analysis \\
\hline Christian & $21(6)$ & $10(3)$ & \multirow{5}{*}{$\begin{array}{l}\text { T2DM in Hindu } \\
\text { community is } \\
39 \% \text { but in Sikh } \\
\text { community, it is } \\
66 \% \text {. }\end{array}$} \\
\hline Hindu & $233(66)$ & $151(43)$ & \\
\hline Muslims & $2(1)$ & $3(1)$ & \\
\hline Sikh & $95(27)$ & $188(54)$ & \\
\hline Total & $351(100)$ & $352(100)$ & \\
\hline \multicolumn{3}{|c|}{ Cooking Media } & \\
\hline Refind Oil & $32(9)$ & $109(30)$ & \multirow{4}{*}{$\begin{array}{l}\text { Mixed oil reduces } \\
\text { risk of T2DM }\end{array}$} \\
\hline Dalda/Sarson & $22(6)$ & $51(15)$ & \\
\hline Mixed & $297(85)$ & 192(55) & \\
\hline Total & $351(100)$ & $352(100)$ & \\
\hline \multicolumn{3}{|l|}{ Sex } & \\
\hline Male & $144(41)$ & $187(53)$ & \multirow{3}{*}{$\begin{array}{l}56 \% \text { of Males is } \\
\text { T2DM and } 44 \% \\
\text { of the Females are } \\
\text { T2DM }\end{array}$} \\
\hline Female & 207 (59) & $165(47)$ & \\
\hline Total & $351(100)$ & $352(100)$ & \\
\hline \multicolumn{3}{|l|}{ Age (Years) } & \multirow{9}{*}{$\begin{array}{l}\text { In control, maximum } \\
\text { age group is } 30-49 \\
\text { and in T2DM, it is } \\
40-69 .\end{array}$} \\
\hline $20-29$ & $37(10)$ & $17(5)$ & \\
\hline $30-39$ & $141(40)$ & $51(15)$ & \\
\hline $40-49$ & $109(31)$ & $78(22)$ & \\
\hline $50-59$ & $43(12)$ & $84(24)$ & \\
\hline $60-69$ & $15(5)$ & $71(20)$ & \\
\hline $70-79$ & $6(2)$ & $44(12)$ & \\
\hline $80-89$ & 0 & $7(2)$ & \\
\hline Total & $351(100)$ & $352(100)$ & \\
\hline Mean & 42.4 & 55.62 & \\
\hline
\end{tabular}

Male and female are more are less matched and use of mixed oil reduces the risk of T2DM.

Table 3. Year of onset, duration of onset of T2DM and Medication.

\begin{tabular}{|c|c|c|}
\hline & T2DM (\%) & Analysis \\
\hline \multicolumn{2}{|l|}{ Year of Onset } & \\
\hline $20-40$ Years & $114(32)$ & \multirow{5}{*}{$\begin{array}{l}7 \% \text { of the subjects are } \\
\text { diseased after } 70 \text { years of } \\
\text { age. }\end{array}$} \\
\hline $41-55$ Years & $152(43)$ & \\
\hline $56-70$ Years & $63(18)$ & \\
\hline$>70$ Years & $23(7)$ & \\
\hline Total & $352(100)$ & \\
\hline \multicolumn{2}{|c|}{ Duration of Onset } & Analysis \\
\hline$<5$ years & 227 (64) & \multirow{6}{*}{$\begin{array}{l}2 \% \text { of the diseased subjects } \\
\text { are living more than } 20 \\
\text { years. Therefore, Evidence } \\
\text { of early mortality. }\end{array}$} \\
\hline $5-10$ Years & $81(23)$ & \\
\hline $11-15$ years & $27(8)$ & \\
\hline $16-20$ Years & $10(3)$ & \\
\hline$>20$ Years & $7(2)$ & \\
\hline Total & $352(100)$ & \\
\hline \multicolumn{2}{|l|}{ Medication } & Analysis \\
\hline Insulin Injection & $21(6)$ & \multirow{3}{*}{$\begin{array}{l}\text { The remaining } 43 \% \text { of the } \\
\text { T2DM subjects have given } \\
\text { medication Nil. }\end{array}$} \\
\hline Oral Medicine & $180(51)$ & \\
\hline Total & $176(57)$ & \\
\hline
\end{tabular}

Table 4. Smoking, Drinking, Hypertension, CHD and Heredity.

\begin{tabular}{|c|c|c|c|}
\hline & Control (\%) & T2DM (\%) & Analysis \\
\hline Smoking & $25(7)$ & 11(3) & \multirow{4}{*}{$\begin{array}{l}\text { T2DM subjects have } \\
\text { High } \% \text { of } \\
\text { hypertension }(49 \%)\end{array}$} \\
\hline Drinking & $53(15)$ & $60(17)$ & \\
\hline Hypertension & $39(11)$ & 173(49) & \\
\hline CHD & 11(3) & $46(13)$ & \\
\hline \multicolumn{3}{|l|}{ Heredity } & Analysis \\
\hline Parents affected & $7(2)$ & $79(23)$ & $\begin{array}{l}23 \% \text { have hereditary } \\
\text { risk factors. }\end{array}$ \\
\hline
\end{tabular}

Table 5. Complications of T2DM Subjects

\begin{tabular}{|c|c|c|}
\hline & Subjects (\%) & \multirow{2}{*}{ Analysis } \\
\hline Retinopathy & $89(25)$ & \\
\hline Cataract & $13(4)$ & \\
\hline Neuropathy & $73(21)$ & \multirow{2}{*}{ Retinopathy is common } \\
\hline Nephropathy & $19(5)$ & \\
\hline Amputation & 0 & \\
\hline Skin Disease & $12(3)$ & \\
\hline Stroke & $4(1)$ & \\
\hline Cancer & $5(1)$ & \\
\hline Asthma & 0 & \\
\hline Thyroid & $17(5)$ & \\
\hline Arthritis & $19(5)$ & \\
\hline Diabetes foot & $14(4)$ & \\
\hline & & \\
\hline & & \\
\hline & & \\
\hline
\end{tabular}

of Chandigarh which is more or less equally matched (Control:T2DM). Since participants are mostly from Chandigarh, there is a possibility of mixing of different traits from different states. Baltana is very close to Chandigarh and also contains immigrant population from Uttarakhand, Jharkhand, Himachal and Punjab apart from the people of Haryana. Moreover, Panchkula and Mohali, both contain people from Haryana, Jammu and Kashmir, Rajasthan, Gujarat etc. Therefore, this research has representation of subjects from all states of North India.

\section{Socioeconomic factors and T2DM}

There are changes in dietary characteristics with religion. Some religious sectors are non-vegetarians and rest is vegetarians. Few vegetarians do not use garlic, onion etc. In a random selection, this result shows the prevalence of T2DM is less in Hindu subjects (39\%) than Sikh subjects (66\%) as per the total recruitment of 384 (Hindu) and 283 (Sikh) subjects. This may be due to the use of deshi ghee, butter and different sweets which have rich glucose in their daily diet. This study is supported by [32] that the Sikh subjects below 40 years old weigh as old as above 40 years which surely will lead to high prevalence of the subjects.

Food affects individuals, T2DM is mainly due to dietary imbalance (taking more saturated fatty acids) [33]. The complicating risk factor, media for cooking was undertaken and found that $85 \%$ of the subjects of control used mixed oil (Olive, refined oil, dalda, sarson, Deshi Ghee etc., change periodically) and only 55\% of T2DM subjects used mixed oil, that is more saturated fatty oil [34]. This gives a close idea that by changing the cooking oil periodically, T2DM subjects may be benefited, though cooking medium alone is not the entire diet.

Sex plays very important role in diabetes due to hormonal changes [35]. This data has more or less equally matched Male and female subjects. This data gives information about male T2DM subjects that they are more susceptible to T2DM than females. Out of 331 male subjects from both control and T2DM, 56\% of them are T2DM subjects whereas out of 372 female subjects from control and T2DM, only $44 \%$ of them are T2DM subjects. This research is similar to this study [36] but against other study [37].

The age group of all participants range from 20 to 89 years and potential control participants are 30-49 years (71\%) and T2DM participants are $40-69$ years (66\%). This is similar to study on Asian Indians that the onset of T2DM in Asian Indians is earlier than other ethnic groups because $40-69$ is considered to be potential age group for 
normal activities. Therefore, early onset of T2DM is observed in north Indian population and this is similar to other studies also [38].

\section{Early onset of T2DM}

The table 3 further highlights the duration of onset of T2DM and $64 \%$ of the T2DM subjects are below 5 years of onset. Only $2 \%$ of the T2DM subjects have duration of T2DM more than 20 years. Due to the early age of onset of T2DM and only $2 \%$ of T2DM subjects have duration of onset of T2DM more than 20 years, we found in this data only $7 \%$ of T2DM subjects have more than 70 years of life which reflects in the high mortality rate of T2DM subjects. Moreover, the high mortality rate may be due to the casual approach to T2DM which is evident from the medication data, only $57 \%$ of the T2DM subjects have followed the proper medication (table 3, insulin injection 6\% and Oral Medicine 51\%) schedule, table 1 and a huge undiagnosed population. This study is in agreement with other studies [39] also.

The complicating risk factors such as smoking and drinking and the allied complication/disorders such as Coronary Heart Diseases (CHD), hypertension etc. adds to the complications of T2DM, table 4. Although, drinking and smoking have been observed less, hypertension is significantly observed in this research however, $23 \%$ of T2DM subjects have genetic origin also, table 4 . All aspects of complications have been analyzed in this research, table 5 with dominant as retinopathy as in other studies [38]. As in this research and other studies, the adjoining areas of the city have migrated people from villages and also have the risk of developing T2DM. The complications due to the changes in life style [40] to them is also in par with the city life style.

\section{Development of early complications}

The age of onset of T2DM in North Indian population is not clearly predictable due to the lack of regular checkups and until the symptoms, T2DM remains undiagnosed for a period of 3 years to 10 years [41] and all of a sudden, all these undiagnosed turn to be chronic diabetic patients [42] with abnormal glucose level etc. [43]. As per this data, T2DM subjects are in the productive age (40 -- 69 years) which is an early stage of onset as compared to other ethnic groups (Approximately 10 years younger in Indians compared with Chinese and Japanese subjects) $[43,44]$. However, it is consistent with the Asian Phenotype. This result is similar to The National Diabetes Urban Survey (NUDS) conducted in India in 2000 which showed that more than $50 \%$ of diabetic cases developed T2DM before the age of 50 years [40]. Since the onset of T2DM is very early compared to other ethnic groups, complications and chronic risks of T2DM are set at an early years, cardiovascular risk [45-47], ischemic heart disease and neuropathy [46], other risks related with early onset of T2DM [48], obesity [49], clinical risk factor [50] agreement with many factors [51] etc. and therefore, mortality rate increases due to T2DM. Another reason is that the media of cooking which increases the body mass index, waist hip ratio and waist circumference, [52-54] lead to obesity, as a result, many other complications get triggered off. The next reason is the hypertension due to high blood pressure as in this research and others $[55,56]$ and the related cardiovascular diseases.

\section{Conclusion}

High prevalence of T2DM is observed in North Indian Population due to early onset of T2DM because of the casual approach to T2DM by the population. T2DM subjects living for high duration (many years) is less due to early onset of complications. Therefore, early mortality and increased mortality due to T2DM (without considering correlated diseases and risk factors) is observed in North Indian Population.

\section{References}

1. Raychaudhuri S (2011) Mapping rare and common causal alleles for complex human diseases. Cell 147: 57-69. [Crossref]

2. Velho G, Byrne MM, Clément K, Sturis J, Pueyo ME, et al. (1996) Clinical phenotypes, insulin secretion, and insulin sensitivity in kindreds with maternally inherited diabetes and deafness due to mitochondrial tRNALeu(UUR) gene mutation. Diabetes 45: 478487. [Crossref]

3. Njølstad PR, Søvik O, Cuesta-Muñoz A, Bjørkhaug L, Massa O, et al. (2001) Neonatal diabetes mellitus due to complete glucokinase deficiency. $N$ Engl J Med 344: 15881592. [Crossref]

4. Cavaghan MK, Ehrmann DA, Polonsky KS (2000) Interactions between insulin resistance and insulin secretion in the development of glucose intolerance. J Clin Invest 106: 329-333. [Crossref]

5. Bell GI, Polonsky KS (2001) Diabetes mellitus and genetically programmed defects in beta-cell function. Nature 414: 788-791.

6. Stumvoll M, Haring H (2002) The peroxisome proliferator-activated receptor-gamma2 Pro12Ala polymorphism. Diabetes 51: 2341-2347.

7. Elsner M, Gehrmann W, Lenzen S (2011) Peroxisome-generated hydrogen peroxide as important mediator of lipotoxicity in insulin-producing cells. Diabetes 60: 200-208.

8. Mohan V, Sandeep S, Deepa R, Shah B, Varghese C (2007) Epidemiology of type 2 diabetes: Indian scenario. Indian J Med Res 125: 217-230. [Crossref]

9. Kaput J (2004) Diet-disease gene interactions. Nutrition 20: 26-31. [Crossref]

10. Irwin M (2002) Effects of sleep and sleep loss on immunity and cytokines. Brain Behav Immun 16: 503-512. [Crossref]

11. Prabhakar NR, Peng YJ (2004) Peripheral chemoreceptors in health and disease. J Appl Physiol (1985) 96: 359-366. [Crossref]

12. Serhan CN, Clish CB, Brannon J, Colgan SP, Chiang N, et al. (2000) Novel functional sets of lipid-derived mediators with antiinflammatory actions generated from omega-3 fatty acids via cyclooxygenase 2-nonsteroidal antiinflammatory drugs and transcellular processing. J Exp Med 192: 1197-1204. [Crossref]

13. Tomita M, Irwin KI, Xie ZJ, Santoro TJ (2002) Tea pigments inhibit the production of type $1(\mathrm{~T}(\mathrm{H} 1))$ and type $2(\mathrm{~T}(\mathrm{H} 2))$ helper T cell cytokines in CD4(+) T cells. Phytother Res 16: 36-42. [Crossref]

14. Gleeson M, Nieman DC, Pedersen BK (2004) Exercise, nutrition and immune function. J Sports Sci 22: 115-125. [Crossref]

15. Irwin, M., et al. (2003) Nocturnal catecholamines and immune function in insomniacs, depressed patients, and control subjects. Brain Behav Immun 17: 365-372. [Crossref]

16. Pandya RJ, Solomon G, Kinner A, Balmes JR (2002) Diesel exhaust and asthma hypotheses and molecular mechanisms of action. Environ Health Perspect $110 \mathrm{Suppl}$ 1: 103-112. [Crossref]

17. Biensø RS, Ringholm S, Kiilerich K, Aachmann-Andersen NJ, Krogh-Madsen R, et al. (2012) GLUT4 and glycogen synthase are key players in bed rest-induced insulin resistance. Diabetes 61: 1090-1099. [Crossref]

18. Chai SY, Pan XY, Song KX, Huang YY, Li F, et al., (2014) Differential patterns of insulin secretion and sensitivity in patients with type 2 diabetes mellitus and nonalcoholic fatty liver disease versus patients with type 2 diabetes mellitus alone. Lipids Health Dis 13: 7. [Crossref]

19. King DE, Mainous AG 3rd, Geesey ME (2008) Adopting moderate alcohol consumption in middle age: subsequent cardiovascular events. Am J Med 121: 201-206. [Crossref]

20. Joosten MM, Chiuve SE, Mukamal KJ, Hu FB, Hendriks HF, et al. (2011) Changes in alcohol consumption and subsequent risk of type 2 diabetes in men. Diabetes 60 : 74-79. [Crossref]

21. Yeh HC, Duncan BB, Schmidt MI, Wang NY, Brancati FL (2010) Smoking, smoking cessation, and risk for type 2 diabetes mellitus: a cohort study. Ann Intern Med 152: 10-17. [Crossref]

22. Wannamethee SG, Shaper AG, Lennon L, Morris RW (2005) Metabolic syndrome vs Framingham Risk Score for prediction of coronary heart disease, stroke, and type 2 diabetes mellitus. Arch Intern Med 165: 2644-2650. [Crossref]

23. Wolf G, Ritz E (2003) Diabetic nephropathy in type 2 diabetes prevention and patient management. J Am Soc Nephrol 14: 1396-1405. [Crossref] 
24. Adler AI, Stevens RJ, Manley SE, Bilous RW, Cull CA, et al. (2003) Development and progression of nephropathy in type 2 diabetes: the United Kingdom Prospective Diabetes Study (UKPDS 64). Kidney Int 63: 225-232. [Crossref]

25. Triplitt CL (2012) Understanding the kidneys' role in blood glucose regulation. Am J Manag Care 18: S11-16. [Crossref]

26. Tso MO, Jampol LM (1982) Pathophysiology of hypertensive retinopathy. Ophthalmology 89: 1132-1145. [Crossref]

27. Kostev K, Jockwig A, Hallwachs A, Rathmann W (2014) Prevalence and risk factors of neuropathy in newly diagnosed type 2 diabetes in primary care practices: a retrospective database analysis in Germany and U.K. Prim Care Diabetes 8: 250-255. [Crossref]

28. Moser JT, Langdon DR, Finkel RS, Ratcliffe SJ, Foley LR, et al. (2013) The evaluation of peripheral neuropathy in youth with type 1 diabetes. Diabetes Res Clin Pract 100: e3-6. [Crossref]

29. WHO, Global status report on noncommunicable diseases 2010. Geneva World Health Organization, 2011.

30. Nwaneri C, Cooper H, Bowen-Jones D (2013) Mortality in type 2 diabetes mellitus: magnitude of the evidence from a systematic review and meta-analysis. British Journal of Diabetes and Vascular Disease 13: 192-207.

31. Mohan V, Shanthirani CS, Deepa M, Deepa R, Unnikrishnan RI, et al. (2006) Mortality rates due to diabetes in a selected urban south Indian population--the Chennai Urban Population Study [CUPS--16]. J Assoc Physicians India 54: 113-117. [Crossref]

32. Singh A, Shenoy S, Sandhu JS (2016) Prevalence of Type 2 Diabetes Mellitus among Urban Sikh Population of Amritsar. Indian J Community Med 41: 263-267. [Crossref]

33. Dyson PA (2016) Saturated fat and Type 2 diabetes: where do we stand? Diabet Med 33: 1312-1314. [Crossref]

34. Mozaffarian D (2014) Saturated fatty acids and type 2 diabetes: more evidence to reinvent dietary guidelines. Lancet Diabetes Endocrinol 2: 770-772. [Crossref]

35. Kautzky-Willer A, Harreiter J, Pacini G (2016) Sex and Gender Differences in Risk, Pathophysiology and Complications of Type 2 Diabetes Mellitus. Endocr Rev 37: 278 316. [Crossref]

36. Karnet B (2012) Type 2 diabetes in men:facing the challenges. Trends Urol Men's Health 3: 19-22.

37. Degaffe GH, Vander Jagt DL, Bobelu A, Bobelu J, Neha D, et al. (2008) Distribution of glyoxalase I polymorphism among Zuni Indians: the Zuni Kidney Project. J Diabetes Complications 22: 267-272. [Crossref]

38. Zou W, Ni L, Lu Q, Zou C, Zhao M, et al. (2016) Diabetes Onset at 31-45 Years of Age is Associated with an Increased Risk of Diabetic Retinopathy in Type 2 Diabetes. Sci Rep 6: 38113. [Crossref]

39. Al-Saeed AH, Constantino MI, Molyneaux L, D'Souza M, Limacher-Gisler F, et al. (2016) An Inverse Relationship Between Age of Type 2 Diabetes Onset and Complication Risk and Mortality:The Impact of Youth-Onset Type 2 Diabetes. Diabetes Care 39: 823-829. [Crossref]

40. Ramachandran A, Snehalatha C, Kapur A, Vijay V, Mohan V, et al. (2001) High prevalence of diabetes and impaired glucose tolerance in India: National Urban Diabetes Survey. Diabetologia 44: 1094-1101. [Crossref]
41. Ginde AA, Delaney KE, Lieberman RM, Vanderweil SG, Camargo CA Jr (2007) Estimated risk for undiagnosed diabetes in the emergency department: a multicenter survey. Acad Emerg Med 14: 492-495. [Crossref]

42. George Savage PE, Kirkwood H, Carter S (2003) Are undiagnosed IGT/IFG and type 2 diabetes common in heart disease and hypertension? . The Brit J Diabetes Vasc Dis 3: 414-416.

43. Qiao Q, Hu G, Tuomilehto J, Nakagami T, Balkau B, et al. (2003) Age- and sexspecific prevalence of diabetes and impaired glucose regulation in 11 Asian cohorts Diabetes Care 26: 1770-1780. [Crossref]

44. Ramachandran A, Snehalatha C, Satyavani K, Sivasankari S, Vijay V (2003) Type 2 diabetes in Asian-Indian urban children. Diabetes Care 26: 1022-1025. [Crossref]

45. Song SH, Hardisty CA (2008) Early-onset Type 2 diabetes mellitus: an increasing phenomenon of elevated cardiovascular risk. Expert Rev Cardiovasc Ther 6: 315-322. [Crossref]

46. Song SH (2015) Complication characteristics between young-onset type 2 versus type 1 diabetes in a UK population. BMJ Open Diabetes Res Care 3: e000044. [Crossref]

47. Hillier TA, Pedula KL (2003) Complications in young adults with early-onset type 2 diabetes: losing the relative protection of youth. Diabetes Care 26: 2999-3005. [Crossref]

48. Wilmot E, Idris I (2014) Early onset type 2 diabetes: risk factors, clinical impact and management. Ther Adv Chronic Dis 5: 234-244. [Crossref]

49. Kissebah AH, Freedman DS, Peiris AN (1989) Health risks of obesity. Med Clin North Am 73: 111-138. [Crossref]

50. Misra A, Luthra K, Vikram NK (2004) Dyslipidemia in Asian Indians: determinants and significance. J Assoc Physicians India 52: 137-142. [Crossref]

51. Yagalla MV, Hoerr SL, Song WO, Enas E, Garg A (1996) Relationship of diet, abdominal obesity, and physical activity to plasma lipoprotein levels in Asian Indian physicians residing in the United States. J Am Diet Assoc 96: 257-261. [Crossref]

52. Kuriyan R, Thomas T, Lokesh DP, Sheth NR, Mahendra A, et al. (2011) Waist circumference and waist for height percentiles in urban South Indian children aged 3-16 years. Indian Pediatr 48: 765-771. [Crossref]

53. Misra A, Vikram NK, Gupta R, Pandey RM, Wasir JS, et al. (2006) Waist circumference cutoff points and action levels for Asian Indians for identification of abdominal obesity. Int J Obes (Lond) 30: 106-111. [Crossref]

54. Warren TY, Dowda WS, Baruth M (2012) Independent Association of Wais Circumference With Hypertension and Diabetes in African American Women, South Carolina, 2007-2009. Prev Chronic.

55. Arauz-Pacheco C, Parrott MA, Raskin P, American Diabetes Association (2003) Treatment of hypertension in adults with diabetes. Diabetes Care 26 Suppl 1: S80-82. [Crossref]

56. Ronnback M, Isomaa B, Fagerudd J, Forsblom C, Groop PH, et al., Complex relationship between blood pressure and mortality in type 2 diabetic patients: a followup of the Botnia Study. Hypertension 47: 168-173. [Crossref]

Copyright: (C2018 Raj R. This is an open-access article distributed under the terms of the Creative Commons Attribution License, which permits unrestricted use, distribution, and reproduction in any medium, provided the original author and source are credited. 